\title{
An age-based demographic analysis of the Caribbean stoplight parrotfish Sparisoma viride
}

\author{
J. H. Choat ${ }^{1, *}$, D. R. Robertson ${ }^{2}$, J. L. Ackerman ${ }^{1}$, J. M. Posada ${ }^{3}$ \\ ${ }^{1}$ School of Marine Biology and Aquaculture, James Cook University, Townsville 4811, Australia \\ ${ }^{2}$ Smithsonian Tropical Research Institute (Panamá), STRI, Unit 0948, APO, AA 34002-0948, USA \\ ${ }^{3}$ Dept. Biología de Organismos, Universidad Simón Bolívar, Apartado 89000, Caracas 1080-A, Venezuela
}

\begin{abstract}
The parrotfish Sparisoma viride is an abundant and ecologically important member of the tropical NW Atlantic reef fish fauna. Sagittal otoliths of 417 individuals were analysed to estimate age-based demographic variables at 4 localities (Lee Stocking Island, Barbados, Los Roques Archipelago and the San Blas Archipelago) spanning $14^{\circ}$ of latitude. The sampling localities ranged from an area protected from trap- and net-based reef fisheries (Los Roques) to an area supporting a dense human population and sustained trapping and spearing for reef fishes including $S$. viride (Barbados). Examination of sectioned sagittal otoliths from each locality revealed regular increments in the sagittal matrix. A preliminary validation at San Blas was consistent with these increments being annual check marks. These increments provided estimates of age structure, maximum longevities and mortality rates for the 4 study populations of $S$. viride. Von Bertalanffy growth functions fitted to each size-at-age plot generated similar growth curves from 3 of these 4 localities. The exception was Lee Stocking, where fish grew faster and reached a substantially larger size than those from the other 3 localities. Further analysis of the growth curves demonstrated that the differences between Lee Stocking and the other localities were attributable to more rapid growth over the first $4 \mathrm{yr}$ of life. Agebased growth curves derived from the Los Roques population were very similar to a size-based curve generated by an independent study on $S$. viride carried out in Bonaire, adjacent to Los Roques. Maximum longevities for all 4 of our populations varied from 7 to 9 yr. Mortality rates generated from catch curve analysis were also similar among localities and suggest that maximum life spans do not exceed 12 yr. This result differs from that obtained at Bonaire, where repeated censuses of tagged fish suggest $30 \mathrm{yr}$ maximum longevity. Abundances of $S$. viride varied 3-fold among localities, being highest at Los Roques (protected from reef fishing), lowest at Barbados (high fishing) and Lee Stocking (low fishing). Thus our age-based study suggests that $S$. viride is a relatively short-lived fish with consistent demographic parameters over a range of localities, latitudes and fishing intensities.
\end{abstract}

KEY WORDS: Age-based demographic properties · Growth · Maximum age $\cdot$ Scarids $\cdot$ Otoliths · Validation · Von Bertalanffy parameters · Geographical variation · Fishing effects

\section{INTRODUCTION}

The stoplight parrotfish Sparisoma viride is an abundant element of the Caribbean reef fish fauna and one of a complex of scarid species confined to reef systems of the tropical western Atlantic (Bernadi et al. 2000). As an excavating substratum feeder (Bellwood 1994) this species is responsible for a significant component of the grazing and bioerosion of Caribbean reefs (Brugger-

${ }^{*}$ Email: john.choat@jcu.edu.au mann et al. 1996, van Rooij et al. 1996a, 1998). More recently $S$. viride has been implicated in the removal of substantial amounts of tissue and underlying skeletal structures of living corals (Bruckner \& Bruckner 1998, 2000). As a functionally dominant species in the Caribbean reef ecosystem (Bruggemann et al. 1996) it is important that we understand the dynamics of $S$. viride, especially its growth and mortality rates. The need for demographic information is also indicated by 
the increasing importance of parrotfishes in regional reef fish catches both in the Pacific and the Atlantic (Polunin \& Roberts 1993, Jennings \& Polunin 1996).

There is a wealth of information on the biology of Sparisoma viride, provided through the research programs of reef fish biologists who studied this species in Bonaire (van Rooij et al. 1995a,b, 1996a,b, Bruggemann et al. 1996, van Rooij \& Videler 1997). These studies have provided a comprehensive picture of the ecology and reproductive biology of this species in Bonaire. An important component of these studies has been the analysis of growth (van Rooij et al. 1995a) and mortality rates (van Rooij \& Videler 1997). These studies were largely size-based and therefore provided limited information on age-specific properties of the study populations or estimates of maximum life spans. Estimates of age structure, longevity and growth rates are a requirement for estimations of population turnover rates and their resilience to different regimes of mortality. Age-based demographic data will extend our knowledge of this species and provide longevity estimates that can be compared to those obtained through changes in size of repeatedly observed or recaptured individuals.

Lack of age-based studies of reef fishes of the Caribbean and adjacent areas may be attributed to difficulties encountered in identifying and counting systematic growth marks in the calcareous structures of fish from tropical regions (Munro 1983). However, there are now a number of studies that have demonstrated the use of growth increments in sagittal otoliths to obtain reliable estimates of age in tropical Atlantic fishes (Bullock et al. 1992, Sadovy et al. 1992, Bush et al. 1996, Luckhurst et al. 2000, Manickchand-Heilman \& Phillip 2000). The present study provides an analysis of the age-based demographic features from populations of Sparisoma viride accessed through reading of growth increments in sagittal otoliths of fishes sampled from 4 widely dispersed Caribbean localities. Our primary interest lies in the estimation of growth parameters, age structure and maximum longevities of these populations. In the case of S.viride the task of estimating demographic parameters could be accomplished with some confidence due to the comprehensive and meticulous studies of this species by van Rooij and his colleagues.

In many reef systems, fishing may influence the demography of fishes (Roberts 1995a, Halpern \& Warner 2002). This is likely to be the case in the Caribbean because of high human densities and the importance of subsistence and commercial fisheries for reef fishes throughout that region (Roberts 1995b, Jackson et al. 2001, Roberts et al. 2002). Varying fishing pressures complicate the analysis of demographic data in coral reef fishes. For example, the demographic estimates provided by van Rooij and his colleagues were obtained from Bonaire, a reef enjoying full protection of its shallow reef fish species. We expected that reefs with the same level of protection would harbour fishes with a greater maximum age compared to those occurring on heavily fished reefs. As authorities responsible for undisturbed reef localities in general are reluctant to allow the sampling necessary for agebased analyses, selection of appropriate comparative localities can be problematical.

Sparisoma viride is a moderately large parrotfish up to $510 \mathrm{~mm}$ fork length, that is widely distributed on coral reefs within the tropical west Atlantic (Bohlke $\&$ Chaplin 1993). The geographical range covers $22^{\circ}$ of latitude extending from the South American Caribbean coast to Bermuda. The status of records of $S$. viride from Brazil have recently been clarified. Sparisoma amplum is now recognised as the sister taxon to $S$. viride (Moura et al. 2001). Over this range populations of $S$. viride will encounter a wide range of water temperatures and occur at a range of local densities. As ectotherms, populations of $S$. viride would be expected to show predictable patterns of variation in growth rates, mean size and longevity over such a latitudinal gradient (Atkinson 1994, Choat \& Robertson 2002, Yamahira \& Conover 2002). Variation in population density and resource availability may also be expected to exert a profound influence on the growth rates and size structure of parrotfish populations (Clifton 1995, Gust et al. 2002). In order to obtain a comprehensive picture of the demography of $S$. viride our sampling was designed to include both a range of fishing intensities and a significant latitudinal gradient within the species' range.

As most Caribbean parrotfishes are caught through trap fisheries (Munro 1983, Koslow et al. 1989, 1994, Sary et al. 1997) our localities were selected on the basis of the prevailing fishery practices. As it was not possible to sample from Bonaire, a major objective was to locate an equivalent area not subject to localised exploitation of parrotfishes. This would provide an adequate comparison with the Bonaire estimates of growth and longevity. In addition, we extended our sampling over $14^{\circ}$ of latitude in order to provide an appropriate context for the interpretation of the growth and longevity estimates. Samples of Sparisoma viride were collected from 4 localities: Lee Stocking Island (Bahamas), Los Roques (northern Venezuela), the San Blas Archipelago (Panama) and Barbados. Details of each locality and their status with respect to fishing are provided below.

Given the potential influences of fishing and localities distributed along a significant latitudinal gradient, we examined the following predictions with respect to demographic trends in Sparisoma viride. 
(1) There will be a positive relationship between growth rates and temperature. The primary prediction is that Sparisoma viride will show increases in growth rate with increased temperatures, especially in the younger age classes. This is in keeping with the findings reported in Atkinson (1994) and Atkinson \& Sibly (1997) where a majority of ectotherms studied showed decreasing individual growth rates with decreasing temperature. As the sampling localities ranged from $23^{\circ} \mathrm{N}$ (Lee Stocking) to $9^{\circ} \mathrm{N}$ (San Blas) and $11^{\circ} \mathrm{N}$ (Los Roques) the latitudinal gradient of $14^{\circ}$ would be sufficient to generate significant sea surface temperature (SST) differences among localities. The alternative prediction is that populations of $S$. viride at higher latitudes will show adaptive variation in somatic growth rates, resulting in greater than expected growth at high latitudes (Yamahira \& Conover 2002).

(2) Maximum size achieved will be greatest at higher latitudes. The primary prediction is that maximum size achieved would be greatest at high-latitude localities where temperatures experienced during development would be lower (Gilligan 1991, Atkinson 1994). In many taxa size at maturity increases as temperature decreases (Atkinson \& Sibly 1997). As we did not collect reproductive information the focus will be on maximum size achieved.

(3) Maximum age achieved will be greatest at higher latitudes. Recent information on tropical reef fishes suggests that populations at higher latitudes will achieve greater maximum ages than those from lower latitudes (Meekan et al. 2001, Choat \& Robertson 2002). Our prediction is that the greatest ages for Sparisoma viride would be recorded from the high-latitude sampling localities.

(4) Intensive fishing will reduce the abundance, maximum size and the maximum age of Sparisoma viride. Fishing has the capacity to reduce numbers of reef fishes especially through trap fisheries over shallow reef areas (Koslow et al. 1989, 1994, Sary et al. 1997). In addition, fishing may also reduce the average size of target species (Halpern \& Warner 2002). For groups such as scarids in which size is related to age (Choat \& Robertson 2002) our expectation would be that intensive fishing would also reduce maximum ages in target species.

(5) Growth rate of Sparisoma viride will decrease with increased density. At a given temperature, increases in food resources will have a positive influence on growth rates (Atkinson \& Sibly 1997). In this study we will use intraspecific density as a proxy for food resources as there is evidence for density-dependent growth patterns and size structures in parrotfishes (Gust et al. 2002).

It was not possible to locate fished and unfished populations at each locality. This means that fishing and location effects will covary along the latitudinal gradient and some confounding between the effects of fishing and location was inevitable. However the degree to which the demographic patterns seen in Sparisoma viride conform to the predictions listed above will provide a framework for a more comprehensive analysis of the response of this species to location effects and fishing pressure.

\section{MATERIALS AND METHODS}

Sampling locations. Within the Caribbean region 4 localities spanning $14^{\circ}$ of latitude (Lee Stocking Island [Bahamas], Barbados, Los Roques Archipelago [Venezuela] and the San Blas Archipelago [Panama]) were sampled (Fig. 1), while estimates of Sparisoma viride abundance were made at all 4 localities plus Bonaire. Details of the geography, reef and population characteristics for each locality plus Bonaire are shown in Table 1. Jamaica, as a heavily fished locality, is included for comparison. The mean annual SSTs at each sampling locality were: Lee Stocking Island, $26.7^{\circ} \mathrm{C}$; Barbados, $27.6^{\circ} \mathrm{C}$; Los Roques, $27.2^{\circ} \mathrm{C}_{\text {; }}$ San Blas, $28.1^{\circ} \mathrm{C}$ (NOAA-CIRES Climate Diagnostics Centre, www.cdc.noaa.gov/).
Fig. 1. Sparisoma viride. Sampling localities within the tropical western Atlantic. Insert shows the reef distribution at Los Roques and the 2 sampling sites within this region. Population sampling and underwater visual censuses were carried out at San Blas, Los Roques, Barbados and Lee Stocking. Bonaire was used for underwater visual censuses only 
Habitat structure varied among localities. In Bonaire and Los Roques the inner margin of the reef flat was dominated by stands of living Acropora palmata. At Lee Stocking Island the shallow water habitat was carbonate rock substratum dominated by gorgonians. Nearshore reef habitats of Barbados comprising spur and groove formations have little living coral and show evidence of recent reef habitat loss (Lewis 2002). Sampling sites at the San Blas Archipelago were on fringing and patch reefs scattered across a shallow $15 \mathrm{~km}^{2}$ platform on the eastern Caribbean coast of Panama and protected from prevailing winds. San Blas is the only continental site we sampled, and the only one with high rainfall and subject to river runoff. D'Croz \& Robertson (1997), Robertson et al. (1999) and papers cited therein provide a detailed environmental description of the study site.

Levels of fishing. Estimates of the levels of fishing are expressed in terms of the number of persons per square kilometre of shallow reef habitat (Table 1). Barbados with an extensive trap fishery (Raitkin \& Kramer 1996, Robichaud et al. 2000) has the greatest number of persons per square kilometre of shallow reef habitat of all the localities investigated. This value is greater than that for Jamaica, a locality subject to severe overfishing through traps (Koslow et al. 1994, Jackson et al. 2001). In Barbados, parrotfishes and especially Sparisoma viride (known locally as 'chubs') are prized food fishes. In contrast, Los Roques has had the status of a national park since 1972. The only substantive shallow-water reef fishery is for lobsters. The prohibition against trapping, spearing and netting of reef fishes is enforced by a permanent staff of the Instituto Nacional de Parques (INPARQUES) and the National Guard. As Barbados and Los Roques are in the same latitudinal stratum, they are expected to provide appropriate contrasts with respect to levels of fishing.

The Exuma Cays study site, Lee Stocking Island, represents an area with minimal fishing for parrotfishes. The Bahamas comprises a system of 700 islands with a land area of $13940 \mathrm{~km}^{2}, 3542 \mathrm{~km}$ of coastline and a population of 295000 . The number of persons per kilometre of coastline, 83, is 2 orders of magnitude less than that at Barbados. Moreover the Exuma Cays study site is situated in one of the least populated areas of the island system. We surveyed local fishers and saw no indications during several visits that Sparisoma viride was exploited at this site, which still supports substantial numbers of lutjanids and large serranids, including Epinephelus striatus (Chiappone et al. 2000).
The San Blas locality had a relatively low number of persons per square kilometre of reef (Table 1). One of us (D.R.R.) visited the archipelago on a monthly basis between 1978 and 1997 and observed local fishing activities. Much of the fishing effort in this study area is directed at pelagic species (carangids and scombrids). The small trap fishery in that area is unlikely to have affected Sparisoma viride during the study period, as traps are set near reef margins or away from reefs. However moderate amounts of subsistence spear fishing may have affected $S$. viride to some extent. Dates of sampling for each locality were as follows: Bahamas, November 1998 and 1999; San Blas, 1995 to 1998; Los Roques and Barbados, July 2000.

Population sampling procedures. The majority of Sparisoma viride sampled for age analysis were speared in shallow areas of reef habitats, although an effort was made to collect terminal-phase individuals across the entire depth range occupied. Small individuals $(<100 \mathrm{~mm}$ SL) were collected in fence nets. In all areas an attempt was made to collect individuals across the observed size range. In San Blas sampling was conducted so as to provide a representative sample of the size range. This was done through a haphazard, 'firstencounter' protocol in which the diver swam in a given direction and collected the first fish encountered regardless of size. However, an attempt also was made to sample the largest individuals present at that study site. The maximum sizes of both initial phase (IP) and terminal phase (TP) fish sampled at San Blas during research 20 to 23 yr earlier (Robertson \& Warner 1978) were similar to those sampled for the present study. Their collections were made at a time of lower human population density and in areas of minimal human presence. A specific aim of the present sampling was to establish maximum sizes of IP and TP phases of $S$. viride and other parrotfishes. Hence it is probable that the largest individuals in the San Blas population were sampled by our collections in the present study. 
Otolith processing. All individuals were measured (SL and FL, mm) and weighed to the nearest gram. There was a consistent relationship between standard length (SL) and fork length (FL), with SL $=0.83$ of FL. Sagittae were removed, cleaned and stored dry. One sagitta from each pair was weighed to the nearest $0.1 \mathrm{mg}$. The sagitta was mounted in thermoplastic cement Crystalbond on a slide edge and ground down to the nucleus using P400 grit abrasive paper with a modified lapidary grinding apparatus. The sagitta was then positioned on a second slide, and the opposite side was also ground down to the nucleus and polished with P800 grit abrasive paper. To improve optical quality, the polished sagitta section was then covered with a thin layer of Crystalbond. Additional details of otolith processing and sectioning are provided in Choat \& Axe (1996). Ground otoliths were examined under both high-power and dissecting microscopes using transmitted light. Each otolith was read at 3 times for annuli. Counts were made along a consistent axis (cf. Choat \& Axe 1996). Inspection of preliminary size-at-age plots indicated that fish $<100 \mathrm{~mm}$ SL were $<1 \mathrm{yr}$ old. Hence sagittae of specimens $<100$ SL mm were polished using $0.3 \mu \mathrm{m}$ alpha aluminium powder, and counts of presumed daily rings were made. These rings were consistent with daily rings examined and validated in other species of parrotfishes (Lou 1992).

Growth and survivorship estimates. Growth curves were generated from size-at-age data obtained from the analysis of 417 sagittal otoliths collected from the 4 sampling localities. The number from each locality and the size range sampled are shown in Table 2. Plots from each locality were partitioned by colour phase. Lifetime growth parameters were estimated by fitting the von Bertalanffy growth function (VBGF):

$$
L_{t}=L_{\infty}\left[1-\exp \left(-K^{\left(t-t_{0}\right)}\right)\right]
$$

where $L_{t}$ is the estimated standard length at age $t_{,} L_{\infty}$ is the mean asymptotic standard length, $K$ is a curvature parameter and $t_{0}$ is the age at which fish have theoret-

Table 2. Sparisoma viride. Sample sizes, size ranges and parameters of the Von Bertalanffy growth function for 4 populations by locality. Intercepts of the growth functions constrained to $10 \mathrm{~mm}$. ( $L_{\infty}$ mean asymptotic standard length; $K$ curvature parameter; $t_{0}$, age of fish at length $0_{i} \mathrm{r}^{2}$, coefficient of determination)

\begin{tabular}{|lcccccc|}
\hline Locality & $\mathrm{n}$ & $\begin{array}{c}\text { Size } \\
(\mathrm{SL} \mathrm{mm})\end{array}$ & $L_{\infty}$ & $K$ & $t_{0}$ & $\mathrm{r}^{2}$ \\
\hline Lee Stocking & 108 & $32-379$ & 357.0 & 0.45 & -0.06 & 0.86 \\
Los Roques & 118 & $61-312$ & 280.6 & 0.60 & -0.06 & 0.77 \\
Barbados & 109 & $72-331$ & 274.5 & 0.71 & -0.05 & 0.69 \\
San Blas & 82 & $48-306$ & 263.7 & 0.82 & -0.05 & 0.76 \\
\hline
\end{tabular}

ical length of 0 . Because VBGF parameter estimates can be sensitive to the range of ages and sizes used (for empirical examples see Ferreira \& Russ 1994, Craig 1999), intercepts were initially constrained to approximate sizes at settlement, $10 \mathrm{~mm}$ (D. R. Robertson pers. obs.). Subsequently $t_{0}$ was constrained to -0.06 for each population, approximating those values attained by constraining length intercepts. Growth estimates were compared by plotting $95 \%$ confidence regions of the parameters $K$ and $L_{\infty}$ (Kimura 1980, Meekan et al. 2001). Growth rates at the first 4 yr of age, expressed as millimetres per year, were calculated from estimates of $K$ and $L_{\infty}: \mathrm{d} L_{t} / \mathrm{d} t=K\left(L_{\infty}-L_{t}\right)$ (Porch et al. 2002). The relationship between otolith weight and increment number was examined using regression analysis. Mortality and survivorship rates were calculated using log-linear regression analyses of age-frequency data, where $S=\mathrm{e}^{-M}$. Fishes younger than 2 yr were excluded from this analysis. Slopes of the regression lines were compared using analysis of covariance (ANCOVA; Zar 1999).

Tagging and validation. To validate the annual nature of the sagittal check marks, a tagging and tetracycline injection program was carried out at the San Blas site during the period 19 to 26 September 1997. The procedures for tagging and tetracycline injection are described in Choat et al. (1996). A total of 60 Sparisoma viride (49 IP and $11 \mathrm{TP}$ individuals) were tagged and released during this period. The model proposed by Cappo et al. (2000) was used to obtain estimates of the periodicity of opaque zone completion. In summary, this model proposes that if each translucent/opaque zone ( 1 cycle) is equivalent to $1 \mathrm{yr}$, then the distance from the tetracycline mark to the outer edge of the otolith, divided by the width of the last complete cycle, should equal the time from mark to recapture. Estimates of length for tagged fish are expressed as fork length.

The analysis of otoliths in the present study satisfies 3 criteria for developing an age-based approach (Fowler \& Doherty 1992).

(1) Otoliths must display an internal structure of increments. For all sagittal otoliths in the 4 populations examined consistent incremental structures were identified in sections of sagittal otoliths (Fig. 2). These were readily counted and measured in the Lee Stocking, Barbados and Los Roques samples. San Blas samples were readable but required additional polishing and careful adjustment of light conditions in order to identify, count and measure opaque zones in the sagittal matrix.

(2) Otolith structure features must be related to some regular timescale. Recapture rates of tagged fish were disappointing compared with those for the Indo-Pacific studies of parrotfishes. However, the double-tagged 


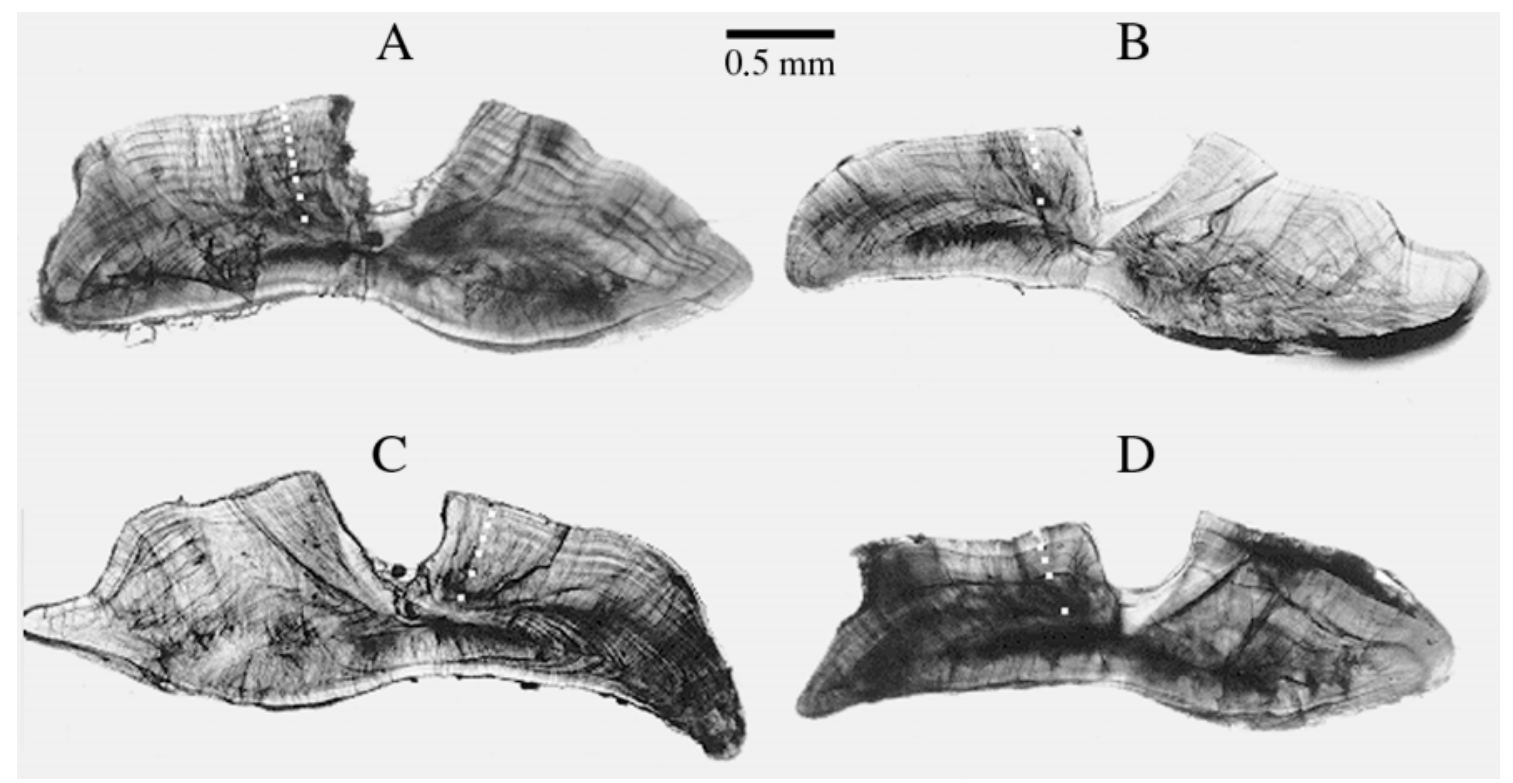

Fig. 2. Sparisoma viride. Representative sectioned sagittae of adults from the 4 sampling localities. () Position of incremental

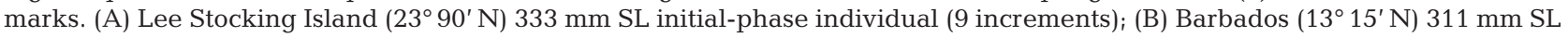
terminal-phase individual (5 increments); (C) Los Roques Archipelago (11 $\left.{ }^{\circ} 80^{\prime} \mathrm{N}\right) 297 \mathrm{~mm}$ SL terminal-phase individual (6 increments); (D) San Blas Archipelago (954' N) 260 mm SL initial-phase individual (5 increments)

individual recovered from the San Blas site after $404 \mathrm{~d}$ at liberty returned a strong tetracycline mark in the sagittal otolith. This enabled us to estimate the predicted otolith growth over $1 \mathrm{yr}$ based on the assumption that intervals between opaque bands represented annual growth in otolith thickness. Our analysis confirmed that the spacing between the opaque zones was consistent with a model of annual growth.

(3) Otoliths must grow throughout the lives of fish at a perceptible rate. Regression of sagittal weight on age yielded significant quadratic relationships. Sagittae of Sparisoma viride accreted weight in a predictable fashion over the lifespan of the fish. The relationship between sagittal weight and age deviated marginally to that observed in similar-sized members of the genus Scarus (Choat et al. 1996, Choat \& Robertson 2002).

Abundance estimates. Counts of Sparisoma viride were made by a single observer (J.H.C.) at all localities using replicated belt transects of $30 \times 10 \mathrm{~m}$ dimensions. In addition, abundance estimates of $S$. viride were made at Bonaire, $150 \mathrm{~km}$ west of Los Roques and in the same latitudinal range $\left(12^{\circ} 20^{\prime} \mathrm{N}\right)$. Counts were made only in shallow reef flats at a depth of 2 to $5 \mathrm{~m}$ and run parallel to the shore. Transects running perpendicular to the shoreline to a depth of $20 \mathrm{~m}$ confirmed the conclusions of van Rooij et al. (1996a) that the $S$. viride population is concentrated in shallow water above that depth. In Los Roques and San Blas the sample areas were immediately seaward of Acropora palmata stands. At Lee Stocking Island counts were made at equivalent depths in reef areas dominated by gorgonians. At Barbados counts were made in 2 habitats: (1) at 2 to $5 \mathrm{~m}$ on the high relief coral matrix habitats usually with a shoreward zone of dead A. palmata (Chapman \& Kramer 2000), and (2) on offshore, gorgonian-dominated bank reefs at 12 to $15 \mathrm{~m}$ depth. Abundance estimates were made for at least 2 sites at each locality with a minimum of 5 replicate transects at each site. Comparative counts were carried out at Bonaire at 3 sites on the west coast in the A. palmata zone (van Rooij et al. 1996b). Counts in Bonaire, San Blas and Lee Stocking Island were made in September 1992. Counts in Los Roques and Barbados were made in July 2000.

Comparison of age- and length-based estimates of growth. In order to obtain an independent assessment of our growth curves we compared the age-generated plots from the Los Roques archipelago with those obtained by van Rooij et al. (1995a) from the reefs of Bonaire. These were generated from their mark-recapture program. These 2 sites are offshore from Venezuela within $1^{\circ}$ of latitude of each other, are separated by only $150 \mathrm{~km}$, and have similar weather regimes and reef characteristics. Most importantly, both reefs are protected from fishing.

\section{RESULTS}

Sectioned sagittae from each population revealed consistent and regular distributions of presumed annuli in the otolith matrix. The distribution of incre- 
ments, comprising alternating broad translucent and narrow opaque zones, in the otolith matrix is shown in Fig. 2. The ease with which these could be identified varied by locality, with those at the highest latitude (Lee Stocking) being the clearest and those from San Blas, the lowest latitude and the only locality adjacent to the mainland coast, being the most difficult to discern. In general there was a strong relationship between sagittal weight and age. Power functions fitted to these bivariate data were significant at all locations. In all 4 populations sagittal accretion slowed with increasing age (Fig. 3).

Size-at-age plots revealed strikingly similar growth trajectories for the Los Roques, Barbados and San Blas populations. However, Sparisoma viride from the Lee Stocking locality achieved a greater size at a given age than those from the localities at lower latitudes (Fig. 4A). Fitting von Bertalanffy growth functions to each data set gave the distribution of parameter values shown in Table 2. The plots of $95 \%$ confidence regions (Fig. 4B) show that the primary differences in the data set lie in the larger mean asymptotic size achieved by the Lee Stocking population. The remaining 3 populations had overlapping values of $K$ and $L_{\infty}$. For each population the estimate of the $L_{\infty}$ was larger in terminal- than in initial-phase individuals (Fig. 4A). The last pattern is consistent with the findings of Robertson \& Warner (1978) in San Blas and of van Rooij et al. (1995a) in Bonaire.

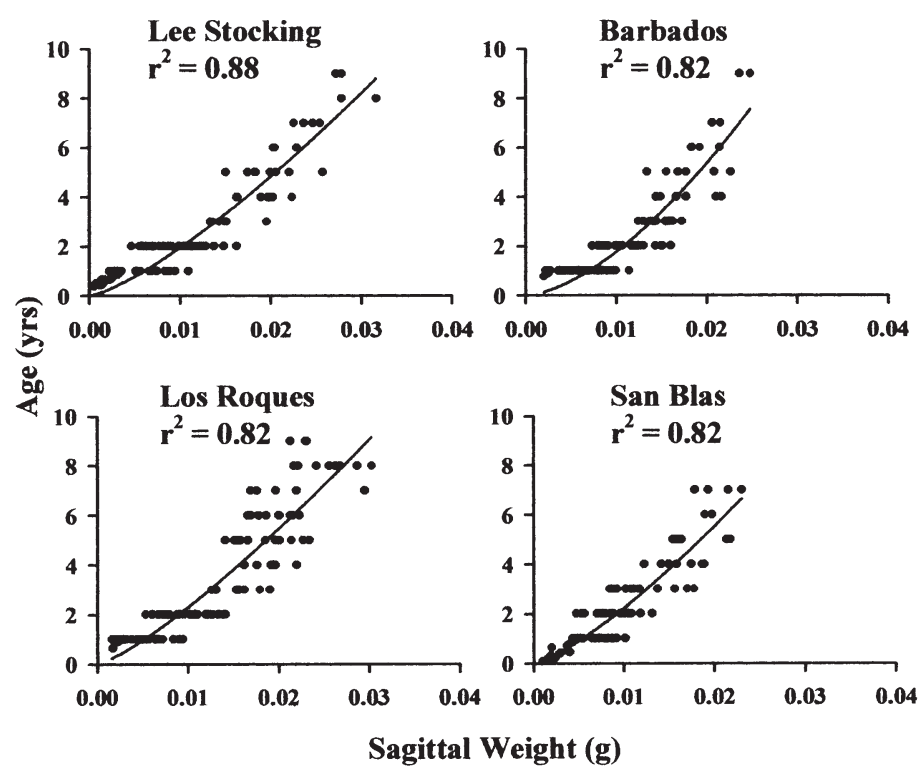

Fig. 3. Sparisoma viride. Power function of sagittal increments (age in years) on sagittal weights $(\mathrm{g})$ in parrotfish sampled from 4 localities. Lee Stocking: $y=801.9 x^{1.3}, \mathrm{n}=106$; Barbados: $y=2759.3 x^{1.6}, \mathrm{n}=109$; Los Roques: $y=712.9 x^{1.2}, \mathrm{n}=118$; San Blas: $y=926.7 x^{1.3}, \mathrm{n}=82$
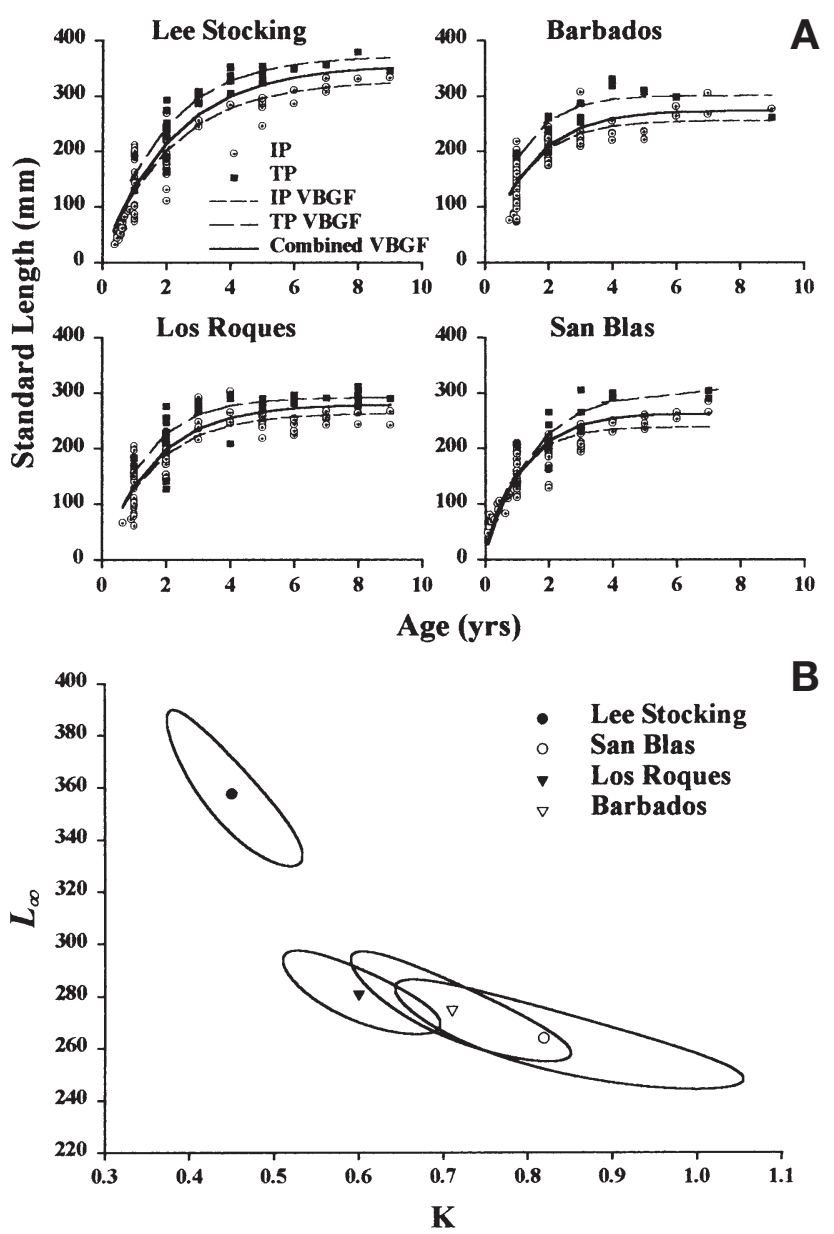

Fig. 4. Sparisoma viride. (A) Size at age plots with fitted von Bertalanffy growth function (VBGF) curves partitioned by initial (IP) and terminal (TP) colour phases and for combined colour phases for each of the 4 sampling localities. VBGF parameters in Table 2. (B) Comparison of VBGF curves for the 4 populations of $S$. viride showing $95 \%$ confidence regions around least squares estimates of $K$ and $L_{\infty}$ following Kimura (1980)

Our size-at-age plots also provided estimates of the maximum longevity achieved in each population (Fig. 4A). The maximum ages observed were similar among the 4 localities. For Lee Stocking, Los Roques and Barbados the greatest age recorded was 9 yr. For San Blas the maximum age was 7 yr. At all 4 localities IP fishes in the samples achieved similar maximum ages to TP fishes, a pattern that is consistent with findings on the distribution of maximum ages of a variety of Indo-Pacific scarids (Choat et al. 1996, Choat \& Robertson 2002).

An IP individual tagged on a patch reef in San Blas on 25 September 1997 was recovered on 2 November 1998. This individual had been double-tagged, as the first T-bar tag inserted was considered to be too loose 

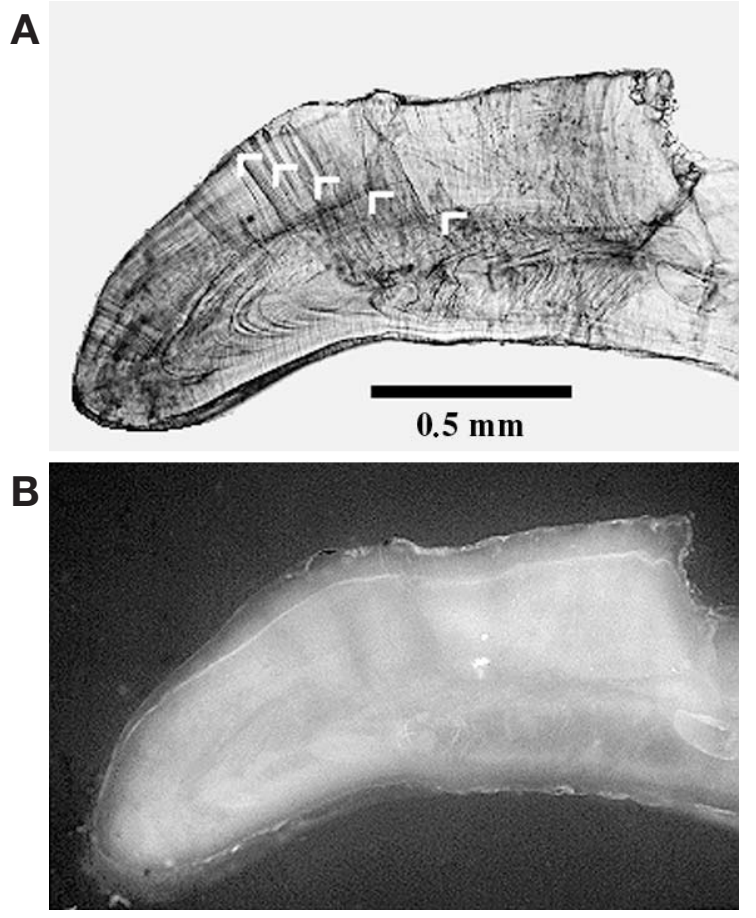

Fig. 5. Sparisoma viride. Sectioned sagittal otolith of a $298 \mathrm{~mm}$ FL initial phase parrotfish from San Blas injected with tetracycline on 25 September 1997 and collected on 2 November 1998. Section photographed under (A) transmitted light with arrows to indicate incremental marks and (B) fluorescent light to display the tetracycline mark

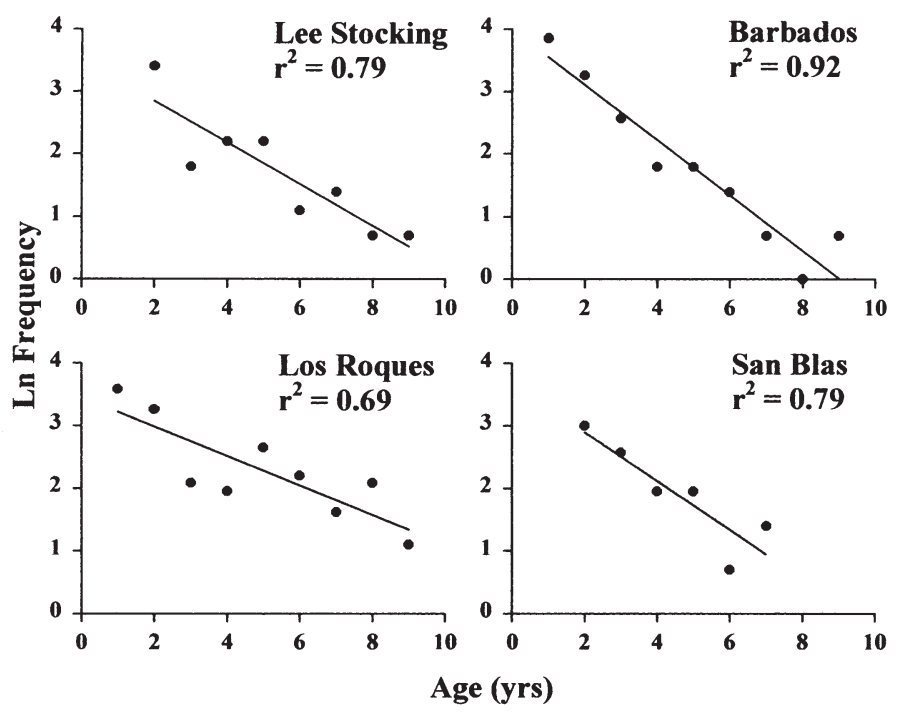

Fig. 6. Sparisoma viride. Catch curves and estimates of mortality in the 4 populations. Lee Stocking: $y=-0.33 x+3.51$; Barbados: $y=-0.44 x+3.99$; Los Roques: $y=-0.24 x+3.46$; San Blas: $y=-0.39 x+3.68$. Regression slopes compared using ANCOVA (Zar 1999). Mortality estimates per yr are: Lee Stocking, 0.33; Los Roques, 0.24; Barbados, 0.44; San Blas, 0.39 for retention at the time of tagging. Both tags were still in place at the time of recapture. The fish had increased in length by $18 \mathrm{~mm}$ to $298 \mathrm{~mm}$ FL over the $404 \mathrm{~d}$ at liberty. The predicted increase in length for a species with these size characteristics based on the independently derived growth curve generated by van Rooij et al. (1995a) was $8 \mathrm{~mm}$. The increase in length shown by this tagged individual was high but within the upper bounds of growth from our size-at-age plots. Our conclusion is that tagging did not have a detrimental effect on growth. The tagged specimen showed a clear tetracycline mark in the sectioned sagitta under fluorescent light (Fig. 5). The distance between the oxytetracycline check mark and the otolith margin, as seen in transverse section of the sagitta, represented growth of the otolith over $1.10 \mathrm{yr}$. Based on the assumption that the distance between opaque bands seen in the transverse section of the sagitta represented $1 \mathrm{yr}$ of otolith growth, we estimated the time at liberty to be $1.09 \mathrm{yr}$ following the model of Cappo et al. (2000). The close correspondence (within $1.3 \%$ ) between these values indicates that the opaque bands are formed annually. Two additional tagged Sparisoma viride (IP) were collected from the tagging site in May 1999. Neither, however, had retained clear tetracycline marks in the sagittae.

An estimate of age distribution was obtained from the San Blas population, where individuals were sampled on a haphazard, 'first encounter' basis to avoid biases through the over-selection of large fishes. The frequency data for age classes provided an age-based catch curve (Fig. 6). At the other localities individuals were sampled in order to obtain a comprehensive set of points for growth curves and for estimates of maximum ages. This resulted in a greater focus on larger and older individuals than at San Blas and a potential to inflate estimates of survivorship. However, plots of the age-class frequency from Lee Stocking, Barbados and Los Roques are very similar to that obtained from San Blas. ANCOVA did not reveal any significant among-locality differences in the mortality rates calculated from the catch curves $(K=4, \mathrm{df}=3,24, F=2.111$, $\mathrm{p}=0.12)$.

Van Rooij et al. (1995a) produced growth curves for Bonaire populations of Sparisoma viride based on sequential measurements of individually identified IP ( $\mathrm{n}=26)$ and TP $(\mathrm{n}=71)$ fish. Their partitioning of the plots between juveniles, IP, and 2 behavioural classes of TP individuals resulted in a series of growth curves from which size at presumed age for each phase could be estimated. We compared these growth curves to those obtained from the adjacent locality of Los Roques (Fig. 7). As we did not distinguish between the different classes of terminal males identified by van Rooij et al. (1995a), our comparison was restricted to growth in juvenile and IP individuals. Superimposing the Bon- 
aire juvenile and IP growth curves on those obtained from Los Roques revealed very similar patterns of average growth at each locality over the first $8 \mathrm{yr}$ of life. However, given the different methodologies used to establish each growth curve, it was not possible to make formal comparisons of the growth parameters (Francis 1988).

The growth curves derived from repeated visual censuses and mark-recapture of Sparisoma viride in the Bonaire populations gave no indication of maximum age attained (van Rooij et al. 1995a). Estimates of mortality for Bonaire populations also derived from repeated visual censuses (van Rooij \& Videler 1997) suggest that $10 \%$ of adult $S$. viride attain an age of $17 \mathrm{yr}$ and that approximately $5 \%$ will achieve an age of $20 \mathrm{yr}$. These latter estimates are double the maximum longevities indicated by the analysis of otoliths of 226 $S$. viride from unfished areas at the same latitude (Los Roques) and at Lee Stocking, $12^{\circ}$ further north. The maximum sizes achieved by TP individuals at Bonaire (374 mm FL) (Bruggemann 1994) and Los Roques (363 mm FL) are fairly similar.

Abundance estimates were obtained from all study localities plus Bonaire (Fig. 8). The study of van Rooij \& Videler 1997 (1997) suggests that numbers from the Bonaire locality were stable over at least 4 yr (1989 to 1992). All samples were taken in equivalent habitat and depth zones with the exception of Barbados Site 2, the offshore bank reef on the western aspect of the island. Two localities, Los Roques and Bonaire, showed consistently high abundances of Sparisoma viride in samples from similar habitats, with means of approximately 7 to 9 ind. $300 \mathrm{~m}^{-2}$. Numbers at the Barbados and Bahamas locality ranged from 2 to 4 ind. $300 \mathrm{~m}^{-2}$.

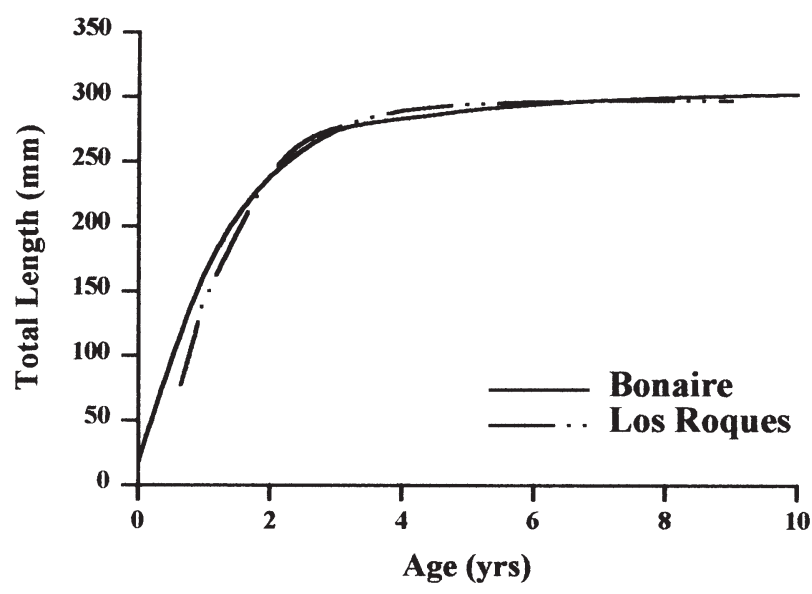

Fig. 7. Sparisoma viride. Predicted growth curves of juvenile and initial phase parrotfish from Bonaire based on markrecapture procedures (van Rooij et al. 1995a), and size-at-age generated growth curve for juvenile and initial-phase fish sampled from Los Roques

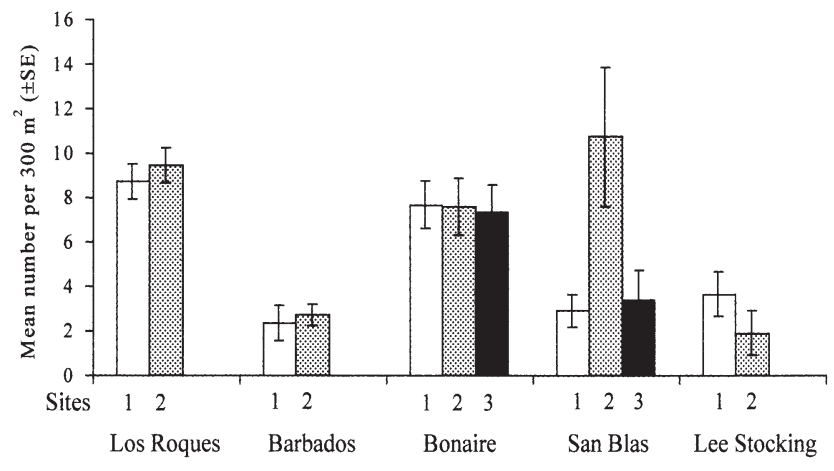

Fig. 8. Sparisoma viride. Estimates of mean abundance of parrotfish obtained from belt-transect counts $(30 \times 10 \mathrm{~m})$ made at equivalent habitat and depth ranges at the 4 sampling localities and Bonaire, $\mathrm{n}=5$ at each site

San Blas showed substantial heterogeneity with 1 site (Aguadargana), returning very high and variable abundance estimates. A consistent feature of this site was elevated abundances but patchy local distributions of $S$. viride. There was no evidence of spawning aggregations at this site. The remaining sites at San Blas showed relatively low abundances.

\section{DISCUSSION}

Table 3 provides a summary of the variation in life history features (mean asymptotic size, maximum age, survivorship and growth over the first $4 \mathrm{yr}$ of life) over the range of localities sampled. We made a number of predictions identifying expected changes in the demographic features of Sparisoma viride sampled over a $14^{\circ}$ latitudinal gradient and exposed to different degrees of fishing intensity. Our results provided both confirmation and contradiction of these predictions (Table 4).

The mean maximum size achieved by Sparisoma viride showed a positive relationship with latitude. The largest $S$. viride (both IP and TP) were collected from the Lee Stocking locality. This trend is in accordance with the extensive literature on the relationship between size and latitudinal position for ectotherms (Atkinson \& Sibly 1997). Smaller mean sizes were recorded from localities subject to increased fishing as would be expected from growth overfishing. Relatively large mean sizes of $S$. viride were recorded from Los Roques, a locality that supported high densities of parrotfishes. This was contrary to expectations from studies on other parrotfish populations, in which high densities were associated with lower mean size (Gust et al. 2002). The relationship between density, mean size and latitudinal position requires further work. 
Table 3. Sparisoma viride. Estimates of 4 life history characters of parrotfish from the 4 study localities. See 'Materials and methods' for details of estimates

\begin{tabular}{|lccccccc|}
\hline Locality & $\begin{array}{c}\text { Mean } \\
\text { asymptotic } \\
\text { size (mm SL) }\end{array}$ & $\begin{array}{c}\text { Max. } \\
\text { age } \\
(\mathrm{yr})\end{array}$ & $\begin{array}{c}\text { Survivor- } \\
\text { ship } \\
\left(\% \mathrm{yr}^{-1}\right)\end{array}$ & \multicolumn{4}{c}{$\begin{array}{c}\text { Growth rate at age } \\
\left(\mathrm{mm} \mathrm{yr}^{-1}\right)\end{array}$} \\
\hline Lee Stocking & 357.0 & 9 & 72 & 99.6 & 63.6 & 40.5 & 25.9 \\
Age 2 & Age 3 & Age 4 \\
Los Roques & 280.6 & 9 & 79 & 89.3 & 49.1 & 27.0 & 14.8 \\
Barbados & 274.5 & 9 & 64 & 92.0 & 45.1 & 22.1 & 10.8 \\
San Blas & 263.7 & 7 & 68 & 86.3 & 49.3 & 28.2 & 16.1 \\
\hline
\end{tabular}

Analysis of growth rates revealed that larger size in the Lee Stocking population was the result of higher growth rates relative to the other populations. The data suggest (Table 3 ) that the trajectories of growth over the first 4 yr of life for Sparisoma viride were responsible for the greater mean size at Lee Stocking. Our initial prediction that growth rate would show a positive relationship with temperature (lower latitude localities) was not confirmed. The growth data suggest some form of latitudinal compensation in growth rates, with populations at higher latitudes showing faster growth (Yamahira \& Conover 2002). The underlying mechanism driving latitudinal compensation is unknown. The higher fishing intensities at Barbados (associated with lower abundances) did not lead to increased initial growth rates, nor did growth rate show a predictable relationship with abundance.

The most counter-intuitive results concerned the maximum ages achieved. Firstly, the age achieved by Sparisoma viride was modest, even for such a relatively short-lived group as scarids (Choat et al. 1996, Choat \& Robertson 2002). The maximum age recorded from the $417 S$. viride sampled from 4 localities was $9 \mathrm{yr}$, with a range from 7 to $9 \mathrm{yr}$. Secondly, the maximum ages recorded from populations from heavily fished localities (Barbados), higher latitudes (Lee Stocking) and from protected reef systems (Los Roques) were all similar (9 yr). Our expectation was that the large size exhibited by $S$. viride at Lee Stocking Island $\left(24^{\circ} \mathrm{N}\right)$ would be attributable to greater longevities (Meekan et al. 2001) and that the heavily fished locality (Barbados) would have younger fishes than the other 3 localities.

The age-based catch curves further suggest that very few individuals, if any, survive $>12$ yr at any location. Although only the San Blas samples were collected on a haphazard, firstencounter basis, biases at the other locations were toward larger individuals. This would have increased the representation of older individuals in these samples, thereby leading to a more conservative estimate of mortality.

Abundance of Sparisoma viride varied predictably over the sampled localities, with the lowest number being recorded at Barbados (fished) and Lee Stocking (high-latitude habitat with limited reef development). Consistently high abundances of $S$. viride were recorded from Los Roques. There was no clear relationship between abundance and maximum ages attained. The Bahamas with 2 to 4 ind. $300 \mathrm{~m}^{-2}$ and Los Roques with approximately treble this number $300 \mathrm{~m}^{-2}$ had similar maximum ages $(9 \mathrm{yr})$ in the sampled populations. Nor were there marked differences in the proportions of terminal males in the adult populations. For Barbados, $20 \%$ of the adult individuals recorded in visual censuses were terminal males, for Los Roques the figure was $18 \%$.

Interpretation of the abundance data is complicated by locality effects and differing degrees of fishing pressure. The greatest abundances were observed at Los Roques and Bonaire, similar reef systems at the same latitude that enjoy protection from human activities. The protected status of Bonaire reefs is unequivocal (Roberts 1998), and parrotfishes at Los Roques $(150 \mathrm{~km}$ west) enjoy the same level of protection as Bonaire. Low population densities at Lee Stocking follow predicted trends of a negative relationship between parrotfish abundance and latitude (Choat 1991). Low abundances of Sparisoma viride in the inshore reef system of Barbados appear to reflect fishing activity. Not only were numerous fish traps encountered during

Table 4. Sparisoma viride. Variation in 4 life history traits analysed for parrotfish populations at 4 localities and under different latitudinal positions, conditions of fishing activity and abundance profiles. (LS, Lee Stocking [Bahamas]; LR, Los Roques [Venezuela]; B, Barbados; SB, San Blas [Panama]. 'Confirmed', 'contradicted' and 'not resolved' refers to predictions made in the 'Introduction'

\begin{tabular}{|lclll|}
\hline Life history trait & Pattern of trait change & Latitude & Fishing & Abundance \\
\hline Mean maximum size & $\mathrm{LS}>\mathrm{LR}>\mathrm{B}>\mathrm{SB}$ & Confirmed & Confirmed & Contradicted \\
Initial growth rate $(4 \mathrm{yr})$ & $\mathrm{LS}>\mathrm{LR}>\mathrm{B}>\mathrm{SB}$ & Contradicted & Contradicted & Not resolved \\
Maximum age & $\mathrm{LS}=\mathrm{LR}=\mathrm{B}>\mathrm{SB}$ & Contradicted & Contradicted & Contradicted \\
Mortality & $\mathrm{B}>\mathrm{SB}>\mathrm{LS}>\mathrm{LR}$ & Confirmed & Confirmed & Contradicted \\
\hline
\end{tabular}


surveys of shallow reefs during this study, but $S$. viride is a highly regarded food fish that is also collected by spearfishers. However the inshore reefs in western Barbados have a relatively poor coral structure (Lawson et al. 1999) compared to Bonaire, Los Roques and San Blas. In addition there is evidence of recent physical degradation of inshore reef systems in Barbados (Lewis 2002). Geographical location, habitat structure, and fishing are all likely to influence abundance profiles in $S$. viride.

The only substantive difference between the demographic conclusions generated by age-based versus size-based methodologies lies in the estimates of mortality and maximum life-span in Sparisoma viride. Van Rooij \& Videler (1997) estimated mortality through repeated visual censuses of the different colour phases of $S$. viride on Bonaire reefs. These censuses yielded survival estimates and ages that were substantially greater than those derived from our age-based analysis. Their pooled survivorship estimates suggest that $25 \%$ of the fish in a cohort will reach an age of $11.5 \mathrm{yr}$; $10 \%$ an age of $17 \mathrm{yr}$; and approximately $5 \%$ an age of 20 yr. Although no estimate of maximum lifespan is given, their survival curves suggest a maximum age of 30 yr. Our sampling program, which included 2 localities with minimal fishing pressure, returned maximum ages of only 9 yr. Estimates of mortality for these samples suggested that ages in excess of $12 \mathrm{yr}$ would be unlikely. With the exception of the San Blas locality our sampling was biased toward larger individuals, which should have produced an overestimate of maximum longevity. Hence it seems unlikely we underestimated longevity.

Our sampling program provided otoliths from a large number of Sparisoma viride of $300 \mathrm{~mm}$ FL or greater. Given the survivorship estimates $(15 \%$ achieving an age of $17 \mathrm{yr}$ or greater) of van Rooij \& Videler (1997) we would have expected to identify an appreciable number of fish between 10 and $15 \mathrm{yr}$ of age had they been present. A total of 74 S. viride $>300 \mathrm{~mm}$ FL were aged from Lee Stocking and Los Roques. None of these had achieved an age of $>9 \mathrm{yr}$. This situation contrasts with Indo-Pacific parrotfishes of the genera Chlorurus and Scarus in which appreciable numbers of individuals between 10 and $20 \mathrm{yr}$ of age were identified from sample sizes, similar to or smaller than those collected in this study (Choat et al. 1996).

Validation of annual growth rings in Caribbean reef fishes through chemical marking of tagged fish has proved to be difficult, with very low tag returns compared to Indo-Pacific reef fishes. Of 270 acanthurid and scarid fishes tagged at San Blas and Lee Stocking Island in 1997 and 1998 only 5 returns were obtained, $<2 \%$. This stands in marked contrast to tagging returns from the Great Barrier Reef, where returns of
$8 \%$ to $25 \%$ were obtained for acanthurid and scarid fishes. The highest returns were obtained mainly from long-lived species (Choat \& Axe 1996, Choat et al. 1996). However, the single return from the San Blas Sparisoma viride population contained a sagittal otolith with a clear tetracycline mark that provides a preliminary validation of an annual pattern of increment formation.

The study of van Rooij et al. (1995a) provided the opportunity to compare the growth curve generated by our size-at-age data with an independently generated growth curve derived from a mark-recapture program. The age-based juvenile and IP growth curves from Los Roques populations were almost identical to those obtained from Bonaire populations using a markrecapture program. Moreover the growth of the tagged individual recaptured from San Blas $(18 \mathrm{~mm}$ increase in fork length over $1.1 \mathrm{yr}$ ) was consistent with the growth curve for IP fishes from Bonaire generated by the mark-recapture program (van Rooij et al.1995a)

The issue of maximum age achieved by this species could be better resolved by sampling over a more extended latitudinal range to include the northern Bahamas $\left(27^{\circ} \mathrm{N}\right)$ and especially Bermuda $\left(33^{\circ} \mathrm{N}\right)$. Bermuda is a locality where parrotfishes are protected, and the difference in average temperature to the Bahamas is similar to that between the Bahamas and Barbados. Sampling of other reef fishes, including scarids, across the same set of sites could help indicate whether this is a general latitudinal pattern rather than one specific in some way to Sparisoma viride.

There was no clear relationship between abundance, fishing and location. It is likely that both fishing and habitat variation (cf. Tolimieri 1998a,b) will influence the abundances of Sparisoma viride, and evaluations of fishing effects may be confounded by habitat variation. This issue can be resolved only if: (1) reserves protect a sufficient range of habitats over a significant latitudinal gradient, and (2) adequate sampling for demographic analyses is allowed over the same set of habitats inside as well as outside reserves at the same set of locations. Such sampling, which would involve a maximum of 50 fish from each locality, would pose little threat to protected populations of species that are relatively short-lived, fast-growing, and occur at high densities.

The critical issue is to obtain sufficient examples of large TP individuals from Bonaire to resolve the issue of longevity in this species and to further assess the role of marine reserves in protecting larger fishes and extending life spans. The protected Bonaire reefs cover an area of approximately $32 \mathrm{~km}^{2}$ (Spalding et al. 2001). A conservative estimate of abundances of adult Sparisoma viride on Bonaire reefs is 4 ind. $300 \mathrm{~m}^{-2}$ ( $50 \%$ of our count data from shallow areas). Scaling up 
this estimate suggests an adult population of $>426000$ $S$. viride on the reefs of Bonaire. A sample of 50 individuals would resolve the issue of longevity and would be unlikely to damage the Bonaire population.

The need to obtain demographic data across as great a range of habitats as possible (including reserve areas) reflects an important management issue, not simply scientific curiosity. If species such as Sparisoma viride are indeed short-lived and rapidly growing fishes, one might expect resilience in the face of increasing fishing pressure. The decline in parrotfish abundances over wide areas of the Caribbean (Jackson et al. 2001) suggests that fishing pressure may be even greater than presently acknowledged.

Acknowledgements. We thank the Fundación Científica Los Roques for providing access to the research facilities at Dos Mosquises (Los Roques archipelago) and the Instituto Nacional de Parques (INPARQUES) for permission to sample fishes at Los Roques; the Caribbean Marine Research Centre for providing facilities at Lee Stocking Island, and the Department of Fisheries, Bahamas for permission to sample fishes; the Smithsonian Institution for providing field facilities in San Blas. The Kuna General Congress and the Government of Panama gave permission for fieldwork in San Blas. The Bellairs Marine Laboratory, McGill University, provided laboratory facilities and access to Barbados reefs. We thank the Bonaire Marine Park authorities for permission to work in the national park; G. Russ, J. Kritzer and P. Munday for the discussion of ideas in this paper; W. Robbins, J. Kritzer, E. Peña, M. von Wangelin, I. Hernandez, and D. Alvarado for assistance with preparation of otoliths, data analysis, field and laboratory assistance. We thank J. Kritzer for development of the VB ConfRegion Macro. James Cook University, the Australian Research Council and the Smithsonian Tropical Research Institution provided funding. Additional support for work in Los Roques and Barbados was also provided by Queensland Government/Smithsonian Institution collaborative grants to J.H.C. and D.R.R.

\section{LITERATURE CITED}

Atkinson D (1994) Temperature and organism size-a biological law for ectotherms? Adv Ecol Res 25:1-58

Atkinson D, Sibly RM (1997) Why are organisms usually bigger in colder environments? Making sense of a life history puzzle. Trends Ecol Evol 12:235-239

Bellwood DR (1994) A phylogenetic study of the parrotfishes family Scaridae (Pisces: Labroidei), with a revision of genera. Rec Aust Mus Suppl 20:1-86

Bernardi G, Robertson DR, Clifton KE, Azzurro E (2000) Molecular systematics, zoogeography, and evolutionary ecology of the Atlantic parrotfish genus Sparisoma. Mol Phylogenet Evol 15(2):292-300

Bohlke JE, Chaplin CCG (1993) Fishes of the Bahamas and adjacent tropical waters, 2nd edn. University of Texas Press, Austin

Bruckner AW, Bruckner RJ (1998) Destruction of coral by Sparisoma viride. Coral Reefs 17:350

Bruckner AW, Bruckner RJ, Sollins P (2000) Parrotfish predation on live coral: 'spot biting' and 'focused biting'. Coral Reefs 19:50
Bruggemann JH (1994) Parrotfish grazing on coral reefs: a trophic novelty. PhD thesis, Department of Marine Biology, University of Groningen

Bruggemann JH, Vankessel AM, van Rooij JM, Breeman AM (1996) Bioerosion and sediment ingestion by the Caribbean parrotfish Scarus vetula and Sparisoma virideimplications of fish size, feeding mode and habitat use. Mar Ecol Prog Ser 134:59-71

Bullock LH, Murphy MD, Godcharles MF, Mitchell ME (1992) Age, growth and reproduction of jewfish, Epinephelus itajara, in the eastern Gulf of Mexico. Fish Bull 90:243-249

Bush PG, Ebanks GC, Lane ED (1996) Validation of ageing techniques for Nassau grouper (Epinephelus striatus) in the Cayman Islands. In: Arreguin-Sanchez F, Munro JL, Balgos MC, Pauly D (eds) Biology, fisheries and culture of tropical snappers and groupers. Conf Proc 48, ICLARM, Manila, p 150-157

Cappo M, Eden P, Newman SJ, Robertson S (2000) A new approach to validation of periodicity and timing of opaque zone formation in the otoliths of eleven species of Lutjanus from the central Great Barrier Reef. Fish Bull 98:474-488

Chapman MR, Kramer DL (2000) Movements of fishes within and among fringing coral reefs in Barbados. Environ Biol Fishes 57:11-24

Chiappone M, Sluka R, Sealy KS (2000) Groupers (Pisces: Serranidae) in fished and protected areas of the Florida Keys, Bahamas and northern Caribbean. Mar Ecol Prog Ser 198:261-272

Choat JH (1991) The biology of herbivorous fishes on coral reefs. In: Sale PF (ed) The ecology of coral reef fishes. Academic Press, New York

Choat JH, Axe LM (1996) Growth and longevity in acanthurid fishes; an analysis of otolith increments. Mar Ecol Prog Ser 134:15-26

Choat JH, Robertson DR (2002) Age-based studies on coral reef fishes. In: Sale PF (ed) Coral reef fishes. Dynamics and diversity in a complex ecosystem. Academic Press, New York

Choat JH, Axe LM, Lou DC (1996). Growth and longevity in fishes of the family Scaridae. Mar Ecol Prog Ser 145:33-41

Clifton KE (1995) Asynchronous food availability on neighboring caribbean coral reefs determines seasonal patterns of growth and reproduction for the herbivorous parrotfish Scarus iserti. Mar Ecol Prog Ser 116:39-46

Craig PC (1999) The von Bertalanffy growth curve: when a good fit is not enough. Naga 22:28-30

D'Croz L, Robertson DR (1997) Coastal oceanographic conditions affecting coral reefs on both sides of the isthmus of Panama. In: Lessios HA, MacIntyre IG (eds) Proc 8th Int Coral Reef Symp 2. Smithsonian Tropical Reserach Institute, Balboa, Panama, p 2053-2058

Ferreira BP, Russ GR (1994) Age validation and estimation of growth rate of the coral trout, Plectropomus leopardus (Lacepede, 1802) from Lizard Island, northern Great Barrier Reef. Fish Bull 92:46-57

Fowler AJ, Doherty PJ (1992) Validation of annual growth increments in the otoliths of two species of damsel fish from the southern Great Barrier Reef. Aust J Mar Freshw Res 43:1057-1068

Francis RICC (1988) Are growth parameters estimated from tagging and age-length data comparable? Can J Fish Aquat Sci 45:936-942

Gilligan MR (1991) Bergmann ecogeographic trends among triplefin blennies (Telostei: Tripterygiidae) in the Gulf of California, Mexico. Environ Biol Fishes 31:301-305

Gust N, Choat JH, Ackerman JL (2002) Demographic plasticity in tropical reef fishes. Mar Biol 140:1023-1037 
Halpern BS, Warner RR (2002) Marine reserves have rapid and lasting effects. Ecol Lett 5:361-366

Jackson JBC, Kirby MX, Berger WH, Bjorndal KA and 15 others (2001) Historical overfishing and the recent collapse of coastal ecosystems. Science 293:629-638

Jennings S, Polunin NVC (1996) Effects of fishing effort and catch rate upon the structure and biomass of Fijian reef fish communities. J Appl Ecol 33:400-412

Kimura DK (1980) Likelihood methods for the von Bertalanffy growth curve. Fish Bull 77:765-774

Koslow JA, Hanley F, Wicklund R (1989) Effects of fishing on reef fish communities of Pedro Bank and Port Royal Cays, Jaimaca. Mar Ecol Prog Ser 43:201-212

Koslow JA, Aiken K, Auil S, Clementson A (1994) Catch and effort analysis of the reef fisheries of Jamaica and Belize. Fish Bull 92:737-747

Lawson GL, Kramer DL, Hunte W (1999) Size-related habitat use and schooling behavior in two species of surgeonfish (Acanthurus bahianus and A. coeruleus) on a fringing reef in Barbados, West Indies. Environ Biol Fish 54:19-33

Lewis JB (2002) Evidence from aerial photography of structural loss of coral reefs at Barbados, West Indies. Coral Reefs 21:49-56

Lou DC (1992) Validation of annual growth bands on the otolith of tropical parrotfishes (Scarus schlegeli Bleeker). J Fish Biol 41:775-790

Luckhurst BE, Dean JM, Reichert M (2000) Age, growth and reproduction of the lane snapper Lutjanus synagris (Pisces: Lutjanidae) at Bermuda. Mar Ecol Prog Ser 203:255-261

Manickchand-Heilman SC, Phillip DAT (2000) Age and growth of the yellowedge grouper, Epinephelus flavolimbatus, and the yellowmouth grouper, Mycteroperca interstitialis, off Trinidad and Tobago. Fish Bull 98:290-298

Meekan MG, Ackerman JL, Wellington GM (2001) Demography and age structure of coral reef damsel fishes in the tropical eastern Pacific Ocean. Mar Ecol Prog Ser 212: 223-232

Moura RL, Figueiredo JL, Sazima I (2001) A new parrotfish (Scaridae) from Brazil and revalidation of Sparisoma amplum (Ranzani, 1842), Sparisoma frondosum (Agassiz, 1831), Sparisoma axillare (Steindachner, 1878) and Scarus trispinosus Valenciennes, 1840. Bull Mar Sci 68:505-524

Munro JL (1983) Coral reef fish and fisheries of the Caribbean Sea. In: Munro JL (ed) Caribbean coral reef fishery resources. ICLARM Stud Rev 7, ICLARM, Manila, p 1-9

Polunin NVC, Roberts CM (1993) Greater biomass and value of target coral-reef fishes in two small Caribbean marine reserves. Mar Ecol Prog Ser 100:167-176

Porch CE, Wilson CA, Nieland DL (2002) A new growth model for red drum (Sciaenops ocellatus) that accommodates seasonal and ontogenic changes in growth rates. Fish Bull 100:149-152

Rakitin A, Kramer DL (1996) Effect of a marine reserve on the distribution of coral reef fishes in Barbados. Mar Ecol Prog Ser 131:97-113

Roberts CM (1995a) Rapid build-up of fish biomass in a Caribbean marine reserve. Conserv Biol 9:815-826

Roberts CM (1995b) Effects of fishing on the ecosystem structure of coral reefs. Conserv Biol 9:988-995

Editorial responsibility: Otto Kinne (Editor), Oldendorf/Luhe, Germany
Roberts CM (1998) Don't shoot the stoplight! Reef Encounter 23:13

Roberts CM, Bohnsack JA, Gell F, Hawkins JP, Goodridge R (2002) Effects of marine reserves on adjacent fisheries. Science 294:1920-1923

Robertson DR, Warner RR (1978) Sexual patterns in the labroid fishes of the western Caribbean. II. The parrotfishes (Scaridae). Smithson Contrib Zool 255:1-26

Robertson DR, Swearer SE, Kaufmann K, Brothers EB (1999) Settlement vs. environmental dynamics in a pelagicspawning reef fish at Caribbean Panama. Ecol Monogr 69: $195-218$

Robichaud D, Hunte W, Chapman MR (2000) Factors affecting the catchability of reef fishes in Antillean fish traps. Bull Mar Sci 67:831-844

Sadovy YM, Figuerola M, Roman A (1992) Age and growth of the red hind Epinephelus guttatus in Puerto Rico and St Thomas. Fish Bull 90:516-528

Sary Z, Oxenford HA, Woodley JD (1997) Effects of an increase in trap mesh size on an overexploited coral reef fishery at Discovery Bay, Jamaica. Mar Ecol Prog Ser 154:107-120

Spalding MD, Ravilious C, Green EP (2001) World atlas of coral reefs. University of California Press, Berkeley

Tolimieri N (1998a) Effects of substrata, resident conspecifics and damselfish on the settlement and recruitment of the stoplight parrotfish, Sparisoma viride. Environ Biol Fishes 53:393-404

Tolimieri N (1998b) The relationship among microhabitat characteristics, recruitment and adult abundance in the stoplight parrotfish, Sparisoma viride, at three spatial scales. Bull Mar Sci 62:253-268

van Rooij JM, Videler JJ (1997) Mortality estimates from repeated visual censuses of a parrotfish (Sparisoma viride) population-demographic implications. Mar Biol 128: 385-396

van Rooij JM, Bruggemann JH, Videler JJ, Breeman AM (1995a) Plastic growth of the herbivorous reef fish Sparisoma viride-field evidence for a trade-off between growth and reproduction. Mar Ecol Prog Ser 122:93-105

van Rooij JM, Bruggemann JH, Videler JJ, Breeman AM (1995b) Ontogenetic social, spatial and seasonal variations in condition of the of the reef herbivore Sparisoma viride. Mar Biol 123:269-275

van Rooij JM, Dejong E, Vaandrager F, Videler JJ (1996a) Resource and habitat sharing by the stoplight parrotfish, Sparisoma viride, a Caribbean reef herbivore. Environ Biol Fishes 47:81-91

van Rooij JM, Kok JP, Videler JJ (1996b) Local variability in population structure and density of the protogynous reef herbivore Sparisoma viride. Environ Biol Fishes 47:65-80

van Rooij JM, Videler JJ, Bruggemann JH (1998) High biomass and production but low energy transfer efficiency of Caribbean parrotfish: implications for trophic models on coral reefs. J Fish Biol 53(Suppl A):154-178

Yamahira K, Conover DO (2002) Intra- vs. interspecific latitudinal variation in growth: adaptation to temperature or seasonality? Ecology 83:1252-1262

Zar JH (1999) Biostatistical analysis, 4th edn. Prentice Hall, Englewood Cliffs, NJ

Submitted: November 26, 2001; Accepted: July 16, 2002

Proofs received from author(s): December 12, 2002 